\title{
Hacia la construcción colectiva del conocimiento sobre el paisaje cultural. La experiencia del movimiento Huelva te mira
}

\author{
Alicia de Navascués Fernández-Victorio | arquitecta \\ URL de la contribución <www.iaph.es/revistaph/index.php/revistaph/article/view/3820>
}

Detrás de movimientos por la cultura y el patrimonio existe una ciudadanía bien formada más allá de los "expertos" a los que se remiten convencionalmente instituciones y medios de comunicación. Los movimientos ciudadanos aglutinan personas de diversas disciplinas que aportan al debate sobre el paisaje cultural un enfoque multidisciplinar moderno y enriquecedor aparte de las tradicionales instancias de decisión en materia cultural, que en general son insuficientemente receptivas a abrirse a la participación efectiva reclamada por la sociedad.

Desde fenómenos como el 15M la ciudadanía ha asumido nuevos protagonismos, también respecto al patrimonio, sobre todo si aprecia que la administración encomendada de su tutela no ejerce tal función con suficiente rigor frente a presiones de la actividad económica y urbanística al margen de criterios de sostenibilidad. La sociedad está cansada de que se gestionen las políticas culturales en foros políticos o elitistas sin contar con ella $\mathrm{y}$, como ejemplo, no ayudan determinadas decisiones

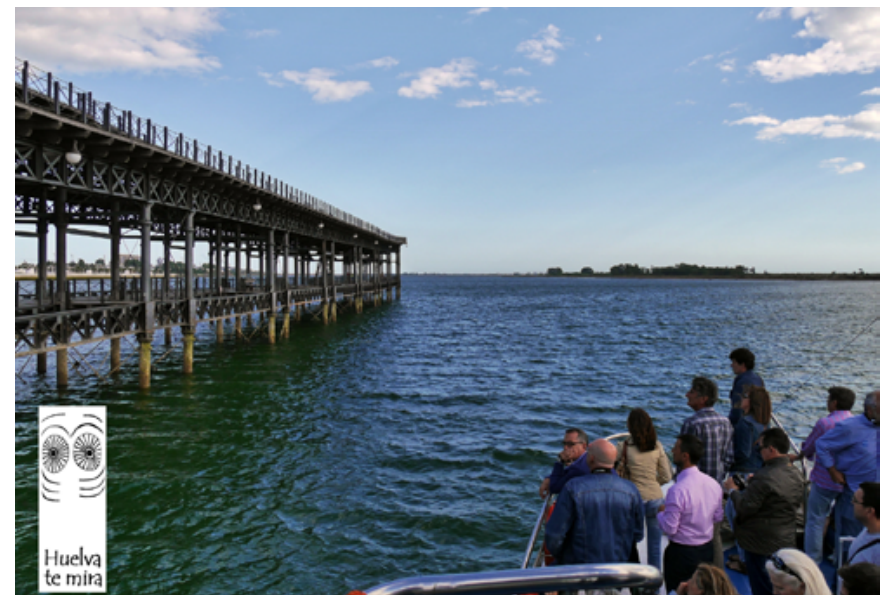

De Muelle a Muelle. Paseo por la ría de Huelva. Actividad de Huelva te mira que olvidan criterios de cohesión territorial en el ámbito de la cultura y el patrimonio. Tal es el caso del recientemente anunciado Eje andaluz de ciudades milenarias que incoherentemente deja fuera a Cádiz y Huelva, sin duda las dos ciudades más antiguas de occidente. En este contexto destaca también la insuficiente difusión de los mecanismos de transmisión del conocimiento científico desde los ámbitos académicos hasta la sociedad.

Damos a conocer un ejemplo de buena práctica de reciente creación: el movimiento ciudadano Huelva te mira $^{1}$ surgido tras una concentración ciudadana el 31 de enero de 2016 como respuesta al escandaloso expolio de un yacimiento milenario en Huelva tras la inacción de la administración local y autonómica. Es una plataforma abierta a la sociedad, reivindicativa, constructiva, transversal, multidisciplinar y participativa. Aborda la construcción colectiva del conocimiento sobre el paisaje cultural onubense, combatiendo el infundado complejo sobre las carencias patrimoniales de Huelva, rompiendo el mito de "hermana fea" de Andalucía sobre el que poco

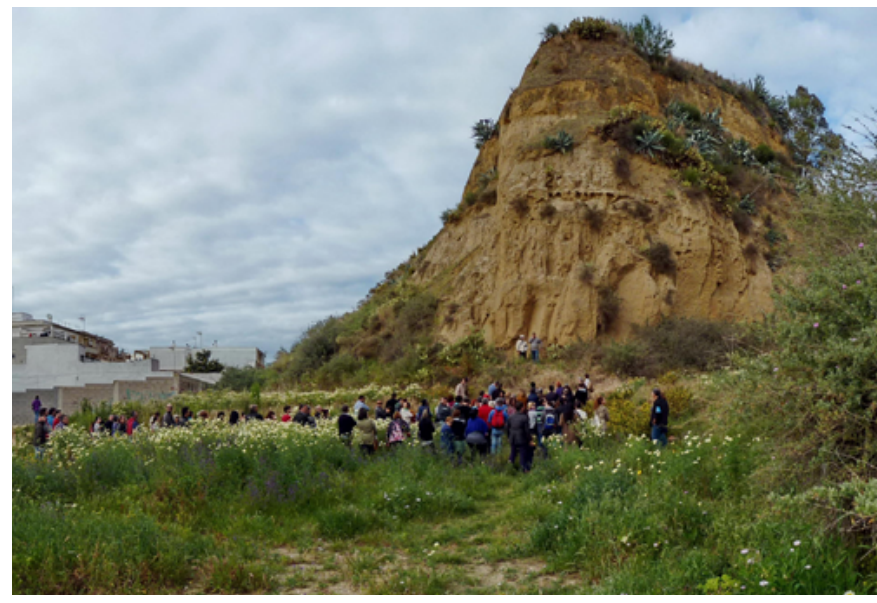

Sendero reivindicativo por los cabezos de Huelva. Actividad de Huelva te mira 


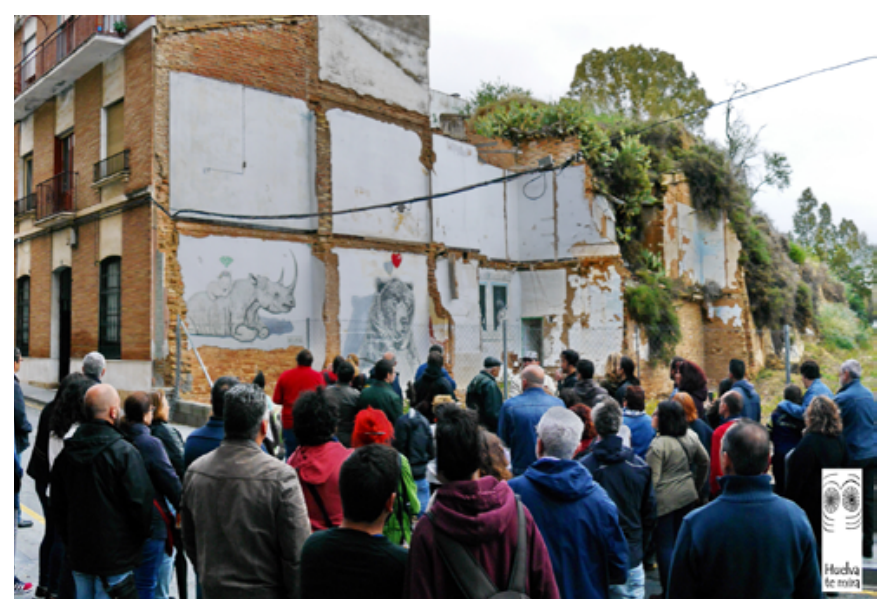

Itinerario de arte urbano. Actividad de Huelva te mira

o nada han hecho las instituciones durante décadas. El rigor, la diversidad e innovación de sus actividades son la garantía de su creciente éxito, del prestigio que está consolidando entre la sociedad, las administraciones y demás instituciones clásicas de gestión cultural. Sus iniciativas están proporcionando además nuevas ideas extrapolables al sector económico de la gestión cultural.

Frente a lo que otras organizaciones más conservadoras puedan pensar, es una buena señal que la sociedad tome iniciativas propias en materia de cultura y patrimonio, con independencia de la administración y del sector académico. Estos dos ámbitos junto con el social son complementarios, aún teniendo sus líneas de actuación específicas y por ello deben crear canales de comunicación mutua. Para garantizar de forma real la participación de la ciudadanía en la toma de decisiones se deben crear consejos de participación en patrimonio por parte de la administración local y autonómica abiertos a las organizaciones, a los movimientos sociales y a la ciudadanía a título individual. Finalmente hay que avanzar hacia la construcción colectiva de la identidad patrimonial desde todos los rincones de nuestro territorio, acercándonos a los barrios y a las periferias,geográficas y culturales.

\section{Nota}

1. https://www.facebook.com/huelvatemira/. 